\title{
Anak di Embung Cinta: Pembentukan Wisata Ramah Anak di Kelurahan Nangkaan Bondowoso
}

\author{
Sapti Prihatmini, Dina Tsalist Wildana, Fanny Tanuwijaya, Al Khanif, Jauhari Zakkiy \\ Annas \\ Fakultas Hukum, Universitas Jember \\ dinawildana@unej.ac.id
}

\begin{abstract}
Abstrak
Kelurahan Nangkaan memiliki keindahan alam berupa embung yaitu cekungan penampung air yang berguna untuk menjaga kualitas air, mencegah banjir dan berguna untuk irigasi sawah. Menariknya embung ini berbentuk hati hingga disebut dengan embung cinta. Keindahan alam ini dimanfaatkan untuk membentuk Desa Wisata Embung Cinta. Lebih khusus, desa wisata ini akan mengusung konsep ramah anak. Metode Asset Based Community Development (ABCD) akan menjadi berbagaikondisi kelurahan Nangkaan sebagai aset yang dapat dikembangkan menuju desa wisata ramah anak. Hasil kegiatan ini adalah berupa kesepakatan ide pembentukan desa wisata ramah anak dari para stake holder meliputi Kepala Pemerintahan Kelurahan Nangkaan, Kelompok Sadar Wisata (Pokdarwis) dan masyarakat. Beberapa program awal yang telah dilakukan adalah menyelenggaran lomba lukis dengan promosi tempat wisata dan membuat konsep wisata ramah anak. Masih banyak tahapan yang harus dilakukan menuju desa wisata ramah anak. Tentunya memerlukan dukungan dari berbagai pihak dan semangat yang harus terus dibangun.
\end{abstract}

Kata Kunci: Desa Wisata, Ramah anak, Asset Based Community Development.

\begin{abstract}
Nangkaan Village is blessed with natural beauty in the form of a reservoir which is a reservoir of water that is useful to maintain water quality, prevent flooding and is useful for irrigation of rice fields. Interestingly, this embung is heart-shaped to be called the embung of love. This natural beauty is used to form the Embung Cinta Tourism Village. More specifically, this tourist village will carry the concept of child- friendly. The Asset Based Community Development (ABCD) method will be a variety of conditions in the Kelangkaan village as an asset that can be developed towards a child-friendly tourism village. The results of this activity are several programs carried out such as holding painting contests and making child-friendly tourism concepts.
\end{abstract}

Keywords: Tourism Village, Child Friendly, Asset Based Community Development

\section{PENDAHULUAN}

Saat ini desa berlomba-lomba mengembangkan potensi wilayah masing-masing, tidak terkecuali desa wisata. Hal ini dapat menjadikan desa menjadi desa mandiri dan berkembang. ${ }^{1}$ Sebelumnya telah bermunculan desa yang berhasil mengembangkan wisatanya seperti menjadikan alam sebagai obyeknya seperti Desa Klaten dengan wisata airnya, Desa Pujon malang dengan wisata cafe dan masih banyak lagi.

1 “Desa Wisata Diyakini Memberi Kemajuan Pengembangan Desa”, (13 August 2019), online: Repub Online 〈https://republika.co.id/share/pw6gsa423〉, Library Catalog: republika.co.id. 
Mengacu pada salah satu kegiatan Kementerian Pemberdayaan Perempuan dan Perlindungan Anak Republik Indonesia yang mengusung program Kabupaten/Kota Layak Anak, dimana mendorong pembangunan berbasis anak. ${ }^{2}$ Program ini selain memiliki landasan yuridis yang kuat baik dari konvensi internasioal maupun perundang-undangan yang berlaku, juga alasan sosiologis bahwa jumlah anak sepertiga dari total jumlah penduduk, dan realitas bahwa anak adalah generasi penerus bangsa. Salah satu indikator Layak Anak adalah pembangunan pendidikan, pemanfaatan waktu luang dan kegiatan budaya dapat berupa menyediaan fasilitas yang ramah anak.

Pembentukan desa wisata telah dilakukan oleh beberapa daerah diantaranya telah mengembangkan konsep ramah anak. Seperti Taman Pintar di Yogyakarta, Taman Wisata Alun-Alun Batu di Malang, dan masih banyak lagi. Terkait hal tersebut, Kabupaten Bondowoso merupakan salah satu kabupaten yang menginisiasi kabupaten layak anak, yaitu memiliki sistem pembangunan yang berbasis hak anak melalui pengintegrasian komitmen dan sumber daya pemerintah, masyarakat dan dunia usaha, yang menyeluruh dan berkelanjutan dalam kebijakan, program dan kegiatan untuk menjamin terpenuhinya hak dan perlindungan anak. ${ }^{3}$ Terkait dua fakta tersebut maka pengabdian ini akan memberikan dorongan untuk pembentukan Desa Wisata Embung Cinta di Kelurahan Nangkaan dengan cita-cita Kabupaten Bondowoso yaitu menjadi kota layak anak, yaitu dengan membentuk desa wisata ramah anak.

\section{METODE}

Pendekatan Asset Based Community Development ( $A B C D$ ) bertumpu pada Asset atau potensi yang sudah dimiliki oleh masyarakat brupa telah adanya potensi berupa embung cinta yang pemanfaatannya memerlukan inovasi. ${ }^{4}$ Kegiatan Pengabdian ini dilaksanakan dengan mengoptimalkan sumber daya manusia (SDM) dari mahasiswa yang melaksanakan Kuliah Kerja Nyata (KKN Unej) dan berkolaborasi dengan SDM Masyarakat setempat khususnya Kelompok Sadar Wisata (Pokdarwis) Kelurahan Nangkaan. Adapun beberapa kegiatan yang dilakukan adalah menyatukan visi membentuk Desa Wisata Embung Cinta, Pengenalan Konsep Wisata Ramah Anak dan Promosi. Metode ABCD memiliki lima langkah kunci untuk melakukan proses riset pendampingan diantaranya ${ }^{5}$ :

\section{A. Inkulturasi (Perkenalan)}

Marty Seligman mengatakan apabila masyarakat lebih peka pada bahaya yang

2 Kabupaten/Kota Layak Anak (Kemeterian Pemberdayaan Perempuan dan Perlindungan Anak Republik Indonesia) at 1.

3 Ibid at Hlm. 1.

4 Christopher Dureau, Pembaru dan kekuatan lokal untuk pembangunan, (Australian Community Development and Civil Society Strengthening Scheme (ACCESS) Tahap II, Agustus 2013), hal. 96-97

5 Christopher Dureau, Pembaru dan kekuatan lokal untuk pembangunan, hal. 96-97 
mengancam, maka akan lebih aman. Hal ini karena masyarakat yang mengenali potensi bahaya yang datang maka akan mempersiapkan berbagai upaya untuk menyelamatkan diri. Maka adalah cukup alamiah apabila masyarakat/komunitas mitra pada tahap awal menekankan penghindaran daripada bersikap positif untuk menjaga keselamatan mereka dan orangorang yang mereka sayangi. Oleh karena itu, tahap inkulturasi menjadi sangat penting dalam kesuksesan sebuah program pengembangan masyarakat. Inkulturasi menjadi sebuah keharusan untuk mengurangi sikap penghindaran dari komunitas mitra sehingga kepercayaan masyarakat dapat terbangun dengan baik. Adapun tujuan dari tahap ini adalah 1) Komunitas mitra memahami maksud /tujuan kegiatan, 2) Membangun kepercayaan komunitas mitra, dan 3) Memfasilitasi kelompok komunitas yang ada menjadi agent of change. ${ }^{6}$

\section{B. Discovery (Menemukan)}

Dilakukan melalui identifikasi informasi-informasi yang memiliki keterkaitan dengan topik pengabdian. Hal ini dilakukan sebelum adanya rencana aksi dan setelah inkulturasi berjalan dengan baik. Pada tahap ini, kegiatan yang dilakukan dapat berupa kegiatan pemetaan asset. Kata asset dipahami tidak selalu dalam bentuk uang. Aset dapat berupa kisah sukses, sejarah komunitas, asosiasi, institusi bahkan warga komunitas mitra merupakan asset yang utama?

\section{Dream (Mimpi)}

Pada tahap ini seluruh elemen menyampaikan mimpinya baik untuk dirinya sendiri maupun untuk desa. kegiatan ini dilakukan dengan cara mewawancarai seluruh elemen masyarakat.

\section{Design (Mobilisasi Aset dan Identifikasi Peluang)}

Pada fase ini perlu identifikasi dan mobilisasi asset adalah untuk membentuk jalan menuju target yang akan dicapai. Pasca identifikasi rampung, maka perlu masyarakat tahu tentang asset yang belum diketahui oleh masyarakat dalam upaya membangun masyarakat berkemajuan. Hasilnya, masyarakat akan mendapatkan energy positif yang selama ini belum disadari. Untuk itu, kegiatan sosialisasi asset menjadi sebuah langkah yang diharapkan mampu membawa semangat democratic governance.

\section{E. Define (Menentukan dan Mendukung Aksi)}

Bila komunitas sudah bisa membayangkan dunianya dengan cara berbeda dan berbagi visi masa depannya, akan ada berbagai jenis kegiatan dengan cakupan yang luas yang dilakukan oleh kelompok dan anggota dengan menggunakan aset mereka untuk mencapai beragam bagian dari mimpi mereka. Masyarakat sudah bisa menentukan bahwa program inilah yang akan menjadi prioritas utama. Program ini akan

6 Agus Afandi, Aplikasi Pendekatan Abcd Dalam Kuliah Kerja Nyata (KKN), UIN Sunan Ampel Surabaya, 6

7 Agus Afandi, Aplikasi Pendekatan Abcd Dalam Kuliah Kerja Nyata (KKN), 7. 
dilaksanakan oleh orang-orang yang sudah berkomitmen untuk melangkah bersama mewujudkan mimpi mereka yang dirumuskan dalam table program kerja. Tanpa kerja sama, maka program kerja yang komunitas putuskan tidak akan mampu berjalan.

\section{F. Destiny (Memastikan)}

Serangkaian tindakan inspiratif yang mendukung proses belajar terus menerus dan inovasi tentang “apa yang akan terjadi." Hal ini merupakan fase akhir yang secara khusus fokus pada cara-cara personal dan organisasi untuk melangkah maju. ${ }^{8}$

\section{HASIL KEGIATAN}

Berdasarkan metode yang telah dirancang maka hasil kegiatan adalah sebagai berikut:

\section{A. Tahap Inkulturasi (Pengenalan)}

Tahap ini dilakukan oleh mahasiswa KKN Unej selama 45 hari bersama dengan perangkat desa dan masyarakat Kelurahan Nangkaan mampu mengenali bahwa aktifitas anak-anak di Kelurahan Nangkaan sebagaimana anak pada umumnya beraktifitas disekolah, kemudian mengaji di TPA setelah pulang dari sekolah. Aktifitas bersantai umumnya dilakukan di dalam rumah dengan bermain game, dan ada pula yang bermain sepeda di sekitar rumah. Hari Minggu kebanyakan dari mereka berkunjung di Alun-Alun Bondowoso bersama dengan orang tua atau bersama teman-teman. Disisi lain Kelurahan Nangkaan telah terbentuk Pokdarwis yang digerakkan oleh kelompok pemuda Karang Taruna diketua oleh Damar Jati Mukti. Obyek yang akan dikembangkan telah ada yaitu Embung Cinta Saat yaitu Embung atau cekungan untuk menampung air yang berguna untuk menjaga kualitas air tanah, mencegah banjir dan irigasi sawah. Disebut embung cinta karena embung di Kelurahan Nangkaan ini berbentuk hati yang umum digunakan sebagai lambang cinta. Selain obyek wisata, Kelurahan Nangkaan juga berkembang UMKM berupa Pabrik Tape Bondowoso, Tape Ungu, Pusat Oleh-oleh khas Bondowoso.

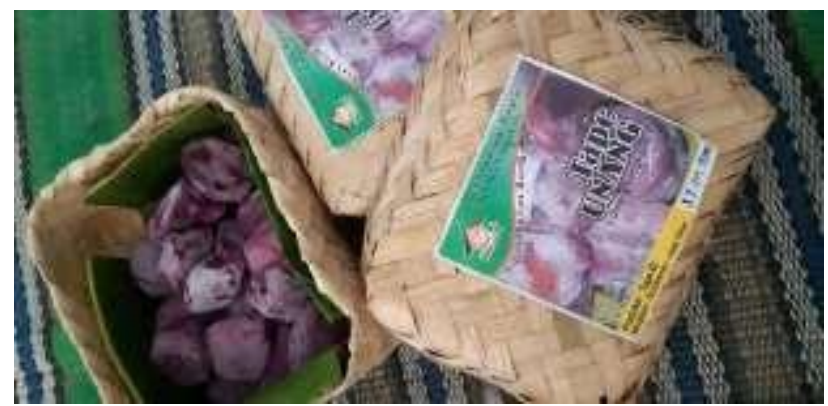

Foto: Ubi Ungu Nangkaan (Unang) Hasil produk unggulan Desa Nagkaan Kabupaten Bondowoso.

8 Christopher Dureau, Pembaru dan kekuatan lokal untuk pembangunan, hal. 96-97 
Setelah mengenal dan memahami berbagai komunitas yang ada di kelurahan Nangkaan langkah berikutnya dalah membangun tujuan bersama dan membangun kepercayaaan melalui berbagai pertemuan, diskusi dan kunjungan secara rutin.

\section{B. Tahap Discovery (Menemukan)}

Kelurahan Nangkaan merupakan salah satu kelurahan yang terletak di Kecamatan Bondowoso. Kelurahan Nangkaan terdiri dari 5000 penduduk dari RT 01 - RT 21 dan RW 01 -RW 05. Tingkat Pendidikan masyarakat di Kelurahan Nangkaan mayoritas adalah lulusan SLTA sehingga dapat disimpulkan bahwa Sumber Daya Manusia (SDM) di Kelurahan Nangkaan termasuk dalam kategori yang cukup baik. Secara Umum masyarakat di Kelurahan Nangkaan bekerja sebagai wiraswasta yang dapat dilihat dari adanya berbagai macam usaha yang ada di Kelurahan Nangkaan.

Dalam bidang ekonomi di Kelurahan Nangkaan terdapat berbagai macam potensi industri tape seperti pabrik tape 31, tape Ubi Ungu Nangkaan (UNANG), dan pabrik tertua di kabupaten bondowoso yaitu tape 82 dan memiliki potensi wisata sumber air yang berbentuk love yang dinamakan sebagai Embung Cinta yang kedepannya diharapkan dapat menjadi icon Kelurahan Nangkaan sehingga dapat mendongkrak perekonomian masyarakat Kelurahan Nangkaan.

Tahap ini dilakukan dengan melibatkan pemerintah Kabupaten Bondowoso dan perangkat Kelurahan Nangkaan bahwa Kabupaten Bondowoso merupakan salah satu kabupaten yang menginisiasi kabupaten layak anak, yaitu memiliki sistem pembangunan yang berbasis hak anak melalui pengintegrasian komitmen dan sumber daya pemerintah, masyarakat dan dunia usaha, yang menyeluruh dan berkelanjutan dalam kebijakan, program dan kegiatan untuk menjamin terpenuhinya hak dan perlindungan anak. Keluarahan Nangkaan siap untuk menjadikan wilayahnya sebagai kota inklusi terhadap anak dalam bentuk desa wisata Ramah Anak.

\section{Dream}

Mimpi kelurahan Nangkaan adalah menjadi Desa Wisata Embung Cinta yang ramah anak. Kelapa Kelurahan menginginkan desa wisata yang terintegrasi antara tempat wisata dan pusat oleh-oleh yang diharapkan mampu meningkatkan perekonomian masyarakat disisi lain Embung Cinta menjadi tempat wisata yang ramah anak

\section{Design}

Embung Cinta masih belum banyak dikenal oleh masyarakat luas. Untuk itu perlu dilakukan promosi yang melibatkan masyarakat umum sehingga Embung Cinta dikenal masyakat luas. Salah satu ide dari Pokdarwis yang berprofesi sebagai pelukis adalah mengadakan kegiatan Lomba Lukis, yang nantinya hasil lukisan akan dipajang di Kelurahan Nangkaan, apabila terjual maka hasilnya akan diberikan kepada pelukis. Lokasi Lukis tentunya di Embung Cinta. masyarakat yang terlibat adalah seluruh pelukis di wilayah tapal kuda. Kedua, mengenalkan konsep dan model desa wisata ramah anak kepada perangkat desa dan Pokdarwis. 


\section{E. Define (Menentukan dan Mendukung Aksi)}

Pelaksaaan design program pertama yaitu lomba lukis adalah sebagai berikut: Pertama, kegiatan lomba lukis. Kegiatan ini bertujuan promosi agar Embung Cinta dikenal oleh masyarakat luas serta menunjukkan awal mula kondisi Embung Cinta pada generasi mendatang. Ketua Pokdarwis yang merupakan pelukis mampu membuka jejaring dengan para pelukis se Tapal Kuda untuk datang dan memeriahkan lomba ini. Konsep lomba lukis dimusyawarahkan dengan perangkat kelurahan Nangkaan dan menghasilkan konsep matang berupa panitia menyediakan peralatan lukis dan konsumsi peserta. Lomba dimulai dari jam 08.00 dan berakhir pukul 12 siang. Hasil lukisan akan diletakkan di Galery tepatnya di kantor Kelurahan Nangkaan. Apabila ada yang berminat maka hasil penjualan akan diberikan kepada pelukis.
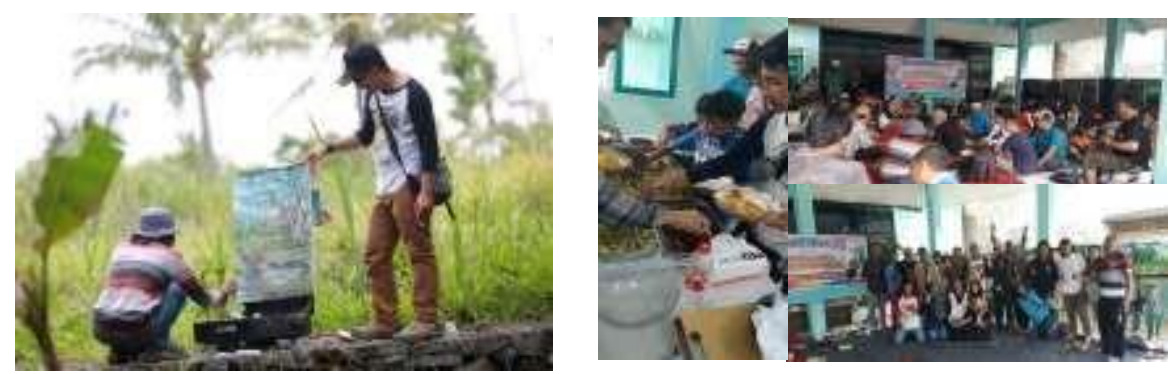

Foto: kegiatan lomba Lukis Embung Cinta

Kegiatan Lomba ini berhasil diliput di berbagai media massa sehingga tujuan promosi ini tercapai. Masyarakat mulai mengenal Embung Cinta di Kelurahan Nangkaan. kegiatan ini membawa optimisme bagi Pokdarwis dan perangkat Desa Nangkaan bahwa Desa Wisata Embung Cinta akan berhasil.

Program kedua adalah membentuk Desa Wisata Embung Cinta yang Ramah Anak. konsep ini berbentuk diskusi bersama tentang konsep wisata ramah anak yang telah ada sebelumnya. Sebagai contoh melihat konsep yang ada di Taman Pintar Yogyakarta, maka wisata ramah anak harus menjamin adanya lokasi bermain yang aman bagi anak-anak, baik dari segi lokasi dan jenis permainannya. Kemudian mengambil konsep Taman Wisata Alun-Alun Batu di Malang, maka wisata ramah anak juga menjamin tersedianya ruang bermain bagi anak yang terbebas dari asap rokok.

Apabila mengacu pada kriteria kementerian pemberdayaan perempuan dan Anak, maka indikator fasilitas ramah anak adalah tersedianya fasilitas untuk kegiatan kreatif dan rekreatif yang ramah anak, diluar sekolah yang dapat diakses oleh semua.9 Ukuran pencapaian indikator ini adalah tersedianya ruang kreatifitas anak yang dapat diakses atau dimanfaatkan oleh semua anak. Ruang Publik ramah anak merupakan suatu tempat yang tersedia dimana anak-anak merasa aman dan nyaman di dalamnya. Disebut aman karena terbebas dari segala bentuk bahaya dan ancaman yang mungkin terjadi seperti bahaya kendaraan, asap rokok maupun berbagai bahan berbahaya serta perlakuan tidak menyenangkan dari orang dewasa. Dalam rangka pembuatan desa wisata ramah anak di Kelurahan Nangkaan disepakati bahwa akan menyisihkan sebagian wilayah untuk ruang 
bermain anak yang bebas dari asap rokok.

Model desa wisata ramah anak di kelurahan Nangkaan mengalami beberapa kali perubahan hingga akhirnya disepakati oleh Kepala Kelurahan. Konsep awal dibuat oleh Pokdarwis yang memiliki jiwa seni, kemudian ide-ide tentang konsep ramah anak dikembangkan dengan menambahkan taman bermain anak, beberapa ruang hijau serta ruang khusus untuk merokok.
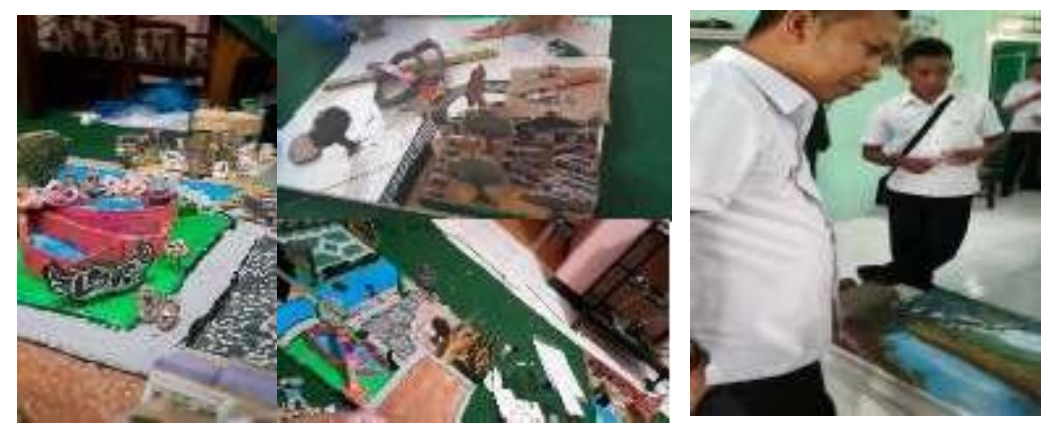

Foto: konsep Desa wisata Ramah Anak Embung Cinta Keluarahan nangkaan dan penyerahan maket ke kepala kelurahan Nangkaan.

\section{F. Destiny (Memastikan)}

Untuk memastikan keberlanjutan tercapainya tujuan Desa Wisata Ramah Anak Embung Cinta di Kelurahan Nangkaan, maka peran aktif pokdarwis menjadi sangat penting. Pokdarwis adalah lembaga swadaya desa yang berperan sebagai penggerak perkembangan pariwisata di tingkat desa. Keberhasilan desa wisata juga tergantung pada peran kepala desa dalam hal ini adalah kepala kelurahan Nangkaan Bondowoso dalam menyediakan falisitas, sarana dan prasarana. Peran serta masyarakat juga tidak kalah penting dalam bentuk dukungan, saran dan masukan agar desa wisata ini semakin berkembang.

\section{KESIMPULAN DAN SARAN}

Pelaksanaan kegiatan pengabdian ini menghasilkan konsep desa wisata ramah anak di Kelurahan Nangkaan. Pihak Pemerintah Daerah dan Pokdarwis sebagai pemamgku kebijakan dan penggerak pariwisata telah memahami langkah-langkah menuju desa wisata ramah anak. Masyarakat memiliki berbagai usaha makanan khas sebagai oleholeh yang menunjang desa wisata. Salah satu upaya promosi untuk mewujudkan desa wisata adalah dengan mengadakan kegiatan lomba lukis yang melibatkan para pelukis untuk menggambarkan keindahakan alam Embung Cinta. Sedangkan untuk membentuk wisata ramah anak, telah dibuat konsep berupa maket yang disusun berdasarkan saran dan masukan semua pihak. 


\section{REKOMENDASI}

Rekomendasi kegiatan ini adalah menjadikan konsep desa wisata ramah anak menjadi lebih lengkap dengan ditunjang sarana prasarana yang baik. Selain itu promosi dan pengembangan harus selalu ditingkatkan agar para pengunjung merasa puas dan nyaman berada di obyek wisata ini.

\section{REFERENSI}

"Desa Wisata Diyakini Memberi Kemajuan Pengembangan Desa”, (13 August 2019), online: Repub Online 〈https://republika.co.id/share/pw6gsa423〉, Library Catalog: republika.co.id.

Agus Afandi, Aplikasi Pendekatan Abcd Dalam Kuliah Kerja Nyata (KKN), UIN Sunan Ampel Surabaya.

Christopher Dureau, Pembaru dan kekuatan lokal untuk pembangunan, (Australian Community Development and Civil Society Strengthening Scheme (ACCESS) Tahap II, Agustus 2013), hal. 96-97

Kabupaten/Kota Layak Anak (Kemeterian Pemberdayaan Perempuan dan Perlindungan Anak Republik Indonesia) 